\title{
Kontribusi Mathematics Anxiety Terhadap Kemampuan Akademik Mahasiswa Pada Pembelajaran Kalkulus
}

\author{
Rifqi Hidayat \\ Program Studi Pendidikan Matematika, Universitas Muhammadiyah Cirebon, \\ JL.Tuparev No.70, Cirebon; rifqi.math@gmail.com
}

Dikirim: 17 Desember 2017; Diterima: 31 Juli 2018; Dipublikasikan: 25 September 2018 Cara sitasi: Hidayat, R. 2018. Kontribusi Mathematics Anxiety Terhadap Kemampuan Akademik Mahasiswa pada Pembelajaran Kalkulus JNPM (Jurnal Nasional Pendidikan Matematika) Vol. 2(2), Hal. 206-216.

\begin{abstract}
Abstrak. Penelitian ini mengkaji hubungan antara mathematics anxiety dengan kemampuan akademik mahasiswa tingkat awal. Penelitian ini didasari oleh performa sebagian besar mahasiswa awal program studi pendidikan matematika masih merasa cemas ketika berhadapan dengan persoalan matematika dalam pembelajaran kalkulus diferensial. Sehingga ketika pembelajaran berlangsung maupun ketika menghadapi persoalan kalkulus, muncul ketidaknyamanan yang dirasakan oleh mahasiswa. Metode penelitian yang digunakan dalam penelitian ini adalah metode survey dengan teknik korelasi. Metode ini digunakan untuk melihat seberapa kuat dan seberapa besar pengaruh mathematics anxiety terhadap kemampuan akademik mahasiswa. Populasi dalam penelitian ini adalah seluruh mahasiswa program studi pendidikan matematika tahun akademik 2016/2017 di FKIP Universitas Muhammadiyah Cirebon, sampel penelitian diambil dengan teknik purposive sampling sebanyak 20 mahasiswa yang mengontrak mata kuliah kalkulus diferensial. Instrumen yang digunakan dalam penelitian ini adalah skala mathematics anxiety. Hasil penelitian menunjukkan bahwa terdapat hubungan yang negatif antara mathematics anxiety dengan kemampuan akademik mahasiswa, serta mathematics anxiety memberikan kontribusi sebesar 35\% terhadap kemampuan akademik mahasiswa, dan 65\% dipengaruhi oleh faktor lain yang tidak diteliti dalam penelitian.
\end{abstract}

Kata kunci: Kontribusi, Mathematics Anxiety, Kemampuan Akademik 


\begin{abstract}
The present study aims to investigate the relationship between Mathematical Anxiety and academic achievement of the first level students. This study is conducted to reveal students' anxiety when they are dealing with mathematical problem in particular Differential Calculus. As the result, students' anxiety significantly rises either in the learning process or specifically when they are encountering with some tasks which are, in this study, related with Calculus differential. This study employs a survey method by using correlation technique. This method is employed to reveal how big the effect of Mathematical Anxiety towards students' academic achievement really is. The population in this study are the entire student of Mathematic Program (Faculty of Teacher Training and Education) Muhammadiyah University of Cirebon Academic Year 2016/2017. Twenty students, who are taking the subject of Calculus Differential, are purposively chosen as the samples of this study. Questionnaire and test are used as the instruments in this study. This study indicates that there is a negative relation between Mathematical Anxiety and students' academic achievement. Mathematical Anxiety contributes $35 \%$ to students' academic achievement. Meanwhile, $65 \%$ is influenced by other factors which are outside the scope of the present study.
\end{abstract}

Key words: Contribution, Mathematics mathematics anxiety and Academic Competence.

\title{
Pendahuluan
}

Matematika adalah salah satu ilmu yang sangat penting dalam kehidupan. Banyak hal yang selalu berhubungan dengan matematika. Matematika dipandang sebagai alat bagi manusia dalam menghadapi perkembangan ilmu pengetahuan, teknologi dan seni yang semakin pesat, oleh sebab itu matematika dinilai mampu dijadikan cara untuk berpikir serta memecahkan persoalan dalam kehidupan sehari-hari. Karena ilmu ini sedemikian penting, maka konsep dasar matematika yang benar dan kuat harus diajarkan kepada seseorang baik pada tingkat pendidikan dasar sampai perguruan tinggi.

Selain itu matematika disebut sebagai ratunya ilmu pengetahuan. Matematika sebagai ratunya ilmu pengetahuan dimaksudkan bahwa matematika adalahsebagai sumber dari ilmu pengetahuan yang lain. Banyak sekali cabang ilmu pengetahuanyang pengembangan teori-teorinya 
didasarkan pada pengembangan konsepmatematika. Sebagai contoh, banyak teori-teori dan cabang-cabang dari fisikadan kimia (modern) yang ditemukan dan dikembangkan melalui konsepkalkulus, khususnya tentang persamaan differensial. Contoh lain, teori ekonomi mengenai permintaan dan penawaran yang dikembangkan melaluikonsep fungsi dan kalkulus tentang differensial dan integral.

Kalkulus adalah mata kuliah yang berguna untuk membantu mahasiswa memantapkan kepribadiannya, agar secara konsisten mampu mewujudkan nilai-nilai dasar matematika untuk menerapkan, mengembangkan bakat dan keahlian (skill),karena ilmu ini bisa membawa kita menuju masa depan yang cerah dan mempunyai rasa tanggung jawab dan bermoral.Namun pada sisi lain, banyak mahasiswa dimanapun menganggap matematika khususnya Kalkulus sebagai ilmu yang sulit dipahami. Harapan matematika sebagai alat berpikir sulit untuk tercapai. Kesulitan terhadap matematika khususnya kalkulus tidak hanya dirasakan oleh mahasiswa pada tingkat dasar dan menengah, tetapi pada tingkat awal perguruan tinggipun terjadi. Sehingga hal ini menyebabkan hasil belajar matematika mahasiswa pada pembelajaran kalkulus khususnya menjadi kurang baik.

Program Studi Pendidikan Matematika merupakan salah satu program studi yang ada di FKIP Universitas Muhammadiyah Cirebon yang mempunyai tugas utama dalam menyelenggarakan pendidikan dan pengajaran dalam bidang pendidikan matematika, di mana output (produk) dari proses pembelajaran tersebut adalah calon guru matematika. Untuk menghasilkan guru matematika yang berkualitas tinggi diperlukan peningkatan segala komponen yang ada di dalam Program Studi Pendidikan Matematika.

Namun capaian akademik mahasiswa pada mata kuliah kalkulus diferensial pada tahun akademik 2015/2016 berada dalam kategori rendah, dari 30 peserta yang dinyatakan lulus pada mata kuliah kalkulus diferensial hanya $50 \%$, sedangkan sisanya tidak lulus. Hal ini menunjukkan bahwa masih banyak mahasiswa yang mengalami kesulitan dan hambatan dalam mempelajari mata kuliah kalkulus diferensial. Capaian yang diharapkan dalam pembelajaran kalkulus diferensial sendiri yaitu dengan nilai ujian mencapai $\geq 70$.

Kenyataan tersebut di atas tentu sangat memprihatinkan bagi semua pihak yang terlibat dalam pengelolaan pendidikan. Pihak yang sangat bertanggung jawab untuk memperbaiki keadaan tersebut di atas adalah dosen matematika khususnya dosen yang mengajar mata kuliah kalkulus diferensial. Untuk itu perlu dilakukan suatu pengkajian secara cermat dan

JNPM (Jurnal Nasional Pendidikan Matematika) Vol. 2, No. 2, Hal. 206-216

p-ISSN 2549-8495, e-ISSN 2549-4937 @Prodi Pendidikan Matematika Unswagati Cirebon 
mendalam mengenai faktor-faktor yang diduga mempengaruhi hasil belajar kalkulus diferensial mahasiswa dan sekaligus merancang dan menerapkan strategi untuk mengatasi permasalahan tersebut di atas. Pada garis besarnya faktor yang mempengaruhi hasil belajar terdiri dari dua bagian besar yaitu faktor internal dan faktor eksternal.

Faktor internal yaitu faktor yang berasal dari dalam diri mahasiswa yang meliputi (1) faktor fisiologis baik yang bersifat bawaan maupun yang diperoleh, (2) faktor psikologis yang terdiri dari faktor intelektual dan non intelektual. Faktor eksternal yaitu faktor yang berasal dari luar diri mahasiswa, seperti kurikulum, guru, metode, faktor sosial, faktor budaya, dan faktor lingkungan (Syah, 2012).

Begitu banyaknya faktor yang telah diidentifikasi yang diduga berpengaruh terhadap hasil belajar mahasiswa dalam mata kuliah Kalkulus Diferensial, maka dirumuskan dan ditetapkan faktor utama yang menjadi bahan kajian pada penelitian ini yaitu penguasaan konsep dasar matematika yang masih lemah, hal ini mengakibatkan mahasiswa selalu merasa tegang, cemas ketika akan mengikuti perkuliahan bahkan ketika akan menghadapi kuis, UTS dan UAS. Berdasarkan uraian tersebut, faktor yang sangat mempengaruhi performa mahasiswa adalah kecemasan terhadap matematika yang tinggi (mathematics anxiety).

Menurut Nietzal (Ghufron dan Risnawati, 2010: 141) Kecemasan berasal dari bahasa latin (anxius) dan dari bahasa jerman (anst), yaitu suatu kata yang digunakan untuk menggambarkan efek negatif dan rangsangan fisiologi. Singgih dan Yulia (2012: 29) mengemukakan kecemasan adalah rasa khawatir, rasa takut yang tidak jelas apa sebabnya. Sukmadinata, (2005: 84) mengemukakan kecemasan merupakan bagian dari emosi yang berkenaan dengan adanya rasa terancam oleh sesuatu yang tidak bergitu jelas dan kecemasan tersebut bisa bernilai positif atau negatif. Kecemasan bernilai positif jika memiliki intensitas yang tidak begitu kuat atau ringan sehingga akan berupa suatu motivasi positif. Jika kecemasan kuat maka bersifat negatif, yakni akan menimbulkan gangguan secara psikis maupun fisik. Berdasarkan pengertian tersebut, kecemasan adalah emosi yang dicirikan dengan perasaan takut, gelisah, khawatir dan tidak tenang terhadap sesuatu yang tidak jelas yang dialami seseorang dalam tingkatan yang berbeda.

Kecemasan menurut Djiwandono dan Wuryani (2009: 387) dijelaskan sebagai berikut: Kecemasan ada dua, yaitu pertama, trait anxiety (sifat kecemasan), yaitu seorang yang mempunyai kecenderungan untuk menjadi cemas atau khawatir barangkali lebih banyak merespon terhadap banyak bentuk situasi,

JNPM (Jurnal Nasional Pendidikan Matematika) Vol. 2, No. 2, Hal. 206-216

p-ISSN 2549-8495, e-ISSN 2549-4937 @Prodi Pendidikan Matematika Unswagati Cirebon 
dengan telapak tangan yang berkeringat, dengan jantung yang berdetak keras. Individu dengan sifat-sifat ini pada umumnya mengalami kecemasan dalam situasi yang lebih luas dan merasa cemasnya lebih sensitif daripada orang lain. Kedua, state anxiety (pernyataan cemas), yaitu kecemasan yang terjadi ketika seseorang mendapat ancaman tertentu. Jadi seseorang yang tidak cemas mungkin menjadi cemas jika dibawah ancaman tertentu.

Kecemasan yang bila dikaitkan dengan pembelajaran matematika termasuk state anxiety yaitu keadaan serta reaksi emosi sementarayang ditentukan oleh perasaan tegang secara subjektif yang timbulpada situasi tertentu yang dirasakan sebagai ancaman, misalnya mengikuti pelajaran matematika. Adapun beberapa pengertian mengenai kecemasan matematika tercermin dalam beberapa pendapat seperti Mathison (1977) mendefinisikan kecemasan matematika sebagai ketakutan irasional matematika yang berkisar dari yang sederhana yaitu ketidaknyamanan yang terkait dengan operasi numerik.

Menurut Ashcraf (2002) kecemasan matematika merupakan perasaan ketegangan, cemas atau ketakutan yang mengganggu kinerja matematika. Seringkali kecemasan yang dialami mahasiswa mengakibatkan mereka menghindari situasi dan kondisi dalam penyelesaian masalah matematika. Sedangkan menurut Richardson dan Suin (Anita, 2010) menyatakan kecemasan matematika melibatkan perasaan tegang dan cemas yang mempengaruhi dengan berbagai cara ketika menyelesaikan soal matematika dalam kehidupan nyata dan akademik. Tidak hanya keterlibatan mahasiswa terhadap pelajaran matematika di sekolah secara akademik, tapi apapun bentuk permasalahan dalam kehidupan sehari-hari selagi bersentuhan dengan angka, maka mahasiswa akan cemas dan tegang.

Menurut Smith (Pleisance, 2010), gejala kecemasan matematika berupa berbagai perasaan gelisah, dan merasa kesulitan bernafas ketika mencoba untuk menyelesaikan tugas-tugas matematika Ada pula gejala fisiologis serta gejala psikologis yang dialami oleh mahasiswa yang mengalami kecemasan matematika. Gejala fisiologis dapat berupa peningkatan denyut jantung, tangan berkeringat, serta sakit perutdan sakit kepala ringan. Gejala psikologis dapat ditunjukan dengan perasaan tidak berdaya atau butuh bantuan, khawatir, dan perasaan tidak mampu dalam bekerja dengan matematika.

Beberapa hasil penelitian diantaranya penelitian yang dilakukan oleh Suparjo (Ekawati, 2015) menunjukkan bahwa tingkat kecemasan siswa dalam menghadapi mata pelajaran matematika cenderung tinggi, sedangkan

JNPM (Jurnal Nasional Pendidikan Matematika) Vol. 2, No. 2, Hal. 206-216

p-ISSN 2549-8495, e-ISSN 2549-4937 @Prodi Pendidikan Matematika Unswagati Cirebon 
penelitian Angreini (2010) menunjukkan hubungan negatif antara kecemasan dengan prestasi belajar matematika, artinya semakin tinggi tingkat kecemasan maka semakin rendah prestasi belajar matematika.

Untuk dapat mengatasi hal tersebut salah satu solusinya adalah dengan memberikan treatment dan pengajaran yang mampumembuat mahasiswa menjadi nyaman di kelas ketika belajar matematika. Selain itu, memberikan pemahaman yang baik tentang manfaat belajar matematika khususnya kalkulus bagi diri mahasiswa serta bagi kehidupan kelak bersaing dalam dunia kerja.

Berdasarkan latar belakang yang diuraikan di atas, maka rumusan masalah dalam penelitian ini adalah sebagai berikut:

1. Bagaimanakah gambaran mathematics anxiety mahasiswa?

2. Bagaimanakah gambaran kemampuan akademik mahasiswa?

3. Apakah ada hubungan antara mathematics anxiety dengan kemampuan akademik mahasiswa?

4. Seberapa besar kontribusi mathematics anxiety terhadap kemampuan akademik mahasiswa?

Tujuan dari penelitian ini adalah untuk mengetahui:

1. Gambaran mathematics anxietymahasiswa.

2. Gambaran kemampuan akademik mahasiswa.

3. Hubungan antara mathematics anxiety dengan kemampuan akademik mahasiswa.

4. Kontribusi mathematics anxiety terhadap kemampuan akademik mahasiswa.

Untuk menjaga agar penelitian ini fokus pada masalah yang akan diteliti, maka peneliti membatasi hal-hal berikut:

1. Subjek penelitian ini adalah mahasiswa tingkat awal Program Studi Pendidikan Matematika UMC yang mengampu mata kuliah kalkulus diferensial pada tahun akademik 2016/2017.

2. Kemampuan akademik yang diukur adalah hasil belajar kalkulus diferensial pada domain kognitif.

\section{Metode Penelitian}

Metode yang digunakan dalam penelitian ini adalah metode survey dengan teknik korelasi yaitu mencari hubungan antara mathematics anxietydengan 
kemampuan akademik mahasiswa. Berikut merupakan desain penelitian yang akan dilakukan (Sugiyono, 2012):

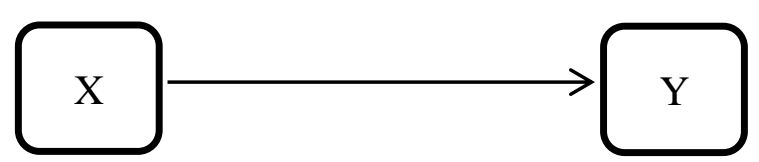

$\mathrm{X}=$ Variabel Mathematics anxiety

$\mathrm{Y}=$ Kemampuan Akademik Mahasiswa

Populasi dalam penelitian ini adalah seluruh mahasiswa Program Studi Pendidikan Matematika di FKIP Universitas Muhamadiyah Cirebon. Sampel penelitian diambil dengan teknik purposive sampling yaitu mahasiswa yang mengontrak mata kuliah Kalkulus Diferensialdi tahun akademik 2016/2017 yang berjumlah 20 orang.

Instrument yang akan digunakan untuk mengukur variabel-variabel dalam penelitian ini adalah:

Tes Kemampuan Akademik

Tes ini digunakan untuk mengukur kemampuan akademik mahasiswa dalam bentuk uraian. Tes ini sudah divalidasi oleh ahli dalam hal ini divalidasi oleh dosen kalkulus diferensial dan evaluasi pembelajaran matematika, sehingga tes ini sudah layak digunakan untuk mengukur kemampuan akademik mahasiswa.

\section{Skala Mathematics anxiety}

Skala ini digunakan untuk mengukur skala mathematics anxiety mahasiswa. Kecemasan matematika (mathematics anxiety) yang dimaksud dalam penelitian ini adalah perasaan tegang, cemas, serta takut yang dialami mahasiswa dalam memanipulasi angka dan menyelesaikan masalah matematika dalam kehidupan sehari-hari dan akademik. Skala ini diadaptasi dari Yuliana (2013) dengan jumlah item pernyataan sebanyak 15 item. Skala mathematics anxiety pada penelitian ini menggunakan skala Likert yang terdiri dari empat pilihan jawaban, yaitu Sangat Setuju (SS), Setuju (S), Tidak Setuju (TS), dan Sangat Tidak Setuju (STS). Mathematics anxiety siswa tentang matematika adalah skor total yang diperoleh siswa setelah memilih pernyataan yang ada pada skala mathematics anxiety.

\section{Hasil dan Pembahasan}

Berikut gambaran mathematics anxiety dan kemampuan akademik mahasiswa sebagai hasil dari penelitian. 
Tabel 1. Gambaran Umum Mathematics anxiety dan Kemampuan Akademik

\begin{tabular}{cccccc}
\hline Variabel & $\mathrm{N}$ & Max & Min & Mean & Std. Dev \\
\hline $\begin{array}{c}\text { Kemampuan } \\
\text { Akademik }\end{array}$ & 20 & 65 & 30 & 53,75 & 8,565 \\
Mathematics anxiety & 20 & 65 & 22 & 40,35 & 6,923 \\
\hline
\end{tabular}

Berdasarkan tabel 1, didapat informasi bahwa rata-rata kemampuan akademik mahasiswa sebesar 53,75 termasuk kedalam kategori rendah dengan deviasi standar 8,565. Adapun untuk mathematics anxiety mahasiswa memperoleh rata-rata sebesar 40,35 dengan deviasi standar 6,923, rataan tersebut termasuk kedalam kategori kecemasan sedang.

Dari hasil analisis data diperoleh hasil seperti pada tabel berikut ini.

Tabel 2. Analisis Korelasi

\begin{tabular}{ccc}
\hline Variabel & Correlation & Keterangan \\
\hline Mathematics Anxiety $><$ & $-0,591$ & Negatif, kuat \\
Kemampuan Akademik & & \\
\hline
\end{tabular}

Berdasarkan tabel 2 di atas, dapat dilihat bahwa hubungan antara mathematics anxietydengan kemampuan akademik mahasiswa adalah sebesar 0,702 . Artinya, hubungan kedua varibel negatif dan tergolong kategori kuat.Dengan demikian semakin tinggi nilai mathematics anxiety mahasiswamaka akan semakin rendah nilai kemampuan akademik mahasiswa pada pembelajaran kalkulusdan sebaliknya.

Tabel 3. Uji Signifikansi Regresi

\begin{tabular}{llrrrrr}
\hline \multicolumn{2}{l}{ Model } & \multicolumn{2}{c}{$\begin{array}{l}\text { Sum of } \\
\text { Squares }\end{array}$} & \multicolumn{4}{c}{ df } & \multicolumn{1}{c}{ Sean } \\
\hline 1 & Regression & 487.496 & 1 & 487.496 & 9.683 & $.006^{a}$ \\
& Residual & 906.254 & 18 & 50.347 & & \\
& Total & 1393.750 & 19 & & & \\
\hline
\end{tabular}

a. Predictors: (Constant), Math_Anxiety

b. Dependent Variable: Kemampuan_Akademik

Berdasarkan hasil uji signifikansi di atas, diperoleh nilai $\mathrm{F}$ hitung sebesar 9,683 dan Sig. yaitu 0,006 kurang dari 0,05. Berarti terdapat hubungan yang signifikan antara mathematics anxiety dengan kemampuan akademik mahasiswa pada pembelajaran kalkulus. 
Untuk melihat seberapa besar kontribusi mathematics anxiety terhadap kemampuan akademik mahasiswa, maka harus dilakukan perhitungan koefisien determinasi. Berikut adalah tabel perhitungan koefisien determinasi.

Tabel 4. Perhitungan Koefisien Determinasi

\begin{tabular}{lrrrr}
\hline Model & R & R Square & $\begin{array}{c}\text { Adjusted R } \\
\text { Square }\end{array}$ & $\begin{array}{l}\text { Std. Error of } \\
\text { the Estimate }\end{array}$ \\
\hline 1 & $.591^{\text {a }}$ & .350 & .314 & 7.096 \\
\hline
\end{tabular}

a. Predictors: (Constant), Math_Anxiety

Berdasarkan tabel 4 di atas, nilai $\mathrm{R}$ Square sebesar 0,350. Maka nilai koefisien determinasinya adalah $=0,350 \times 100 \%=35 \%$. Hal ini memberikan gambaran bahwa kontribusi mathematics anxietyterhadap kemampuan akademik mahasiswa adalah sebesar 35\%. Selebihnya sebesar 65\% dipengaruhi oleh variabel lain.

Hasil penelitian terhadap mahasiswa semester awal Program Studi Pendidikan Matematika Universitas Muhammadiyah Cirebon diperoleh bahwa mathematics anxiety mempunyai hubungan yang negatif dan signifikan dengan kemampuan akademik mahasiswa.Hal ini berarti bahwa tinggi rendahnya mathematics anxiety mempengaruhi kemampuan akademik mahasiwa. Berdasarkan hasil penelitian tersebut, didapat bahwa rata-rata mathematics anxiety mahasiswa tergolong sedang, artinya mahasiswa pada masa awal kuliah memiliki kecemasan belajar yang berarti. Sehingga jika mathematics anxiety pada diri mahasiswa bisa diturunkan akan memberikan efek positif terhadap peningkatan hasil belajarnya.

Berdasarkan hasil belajar mahasiswa yang diperoleh belum menunjukkan hasil yang optimal. Hal ini terlihat dari nilai rata-rata hasil belajar mahasiswa tergolong kedalam kategori rendah. Hasil belajar yang diperoleh oleh mahasiswa ini jelas belum sesuai dengan harapan, karena belum mencapai target yang ditetapkan diawal perkuliahan. Mata kuliah Kalkulus merupakan mata kuliah dasar yang sangat penting dikuasi oleh mahasiswa untuk memahami mata kuliah lain pada rumpun yang sama. Sehingga keberhasilan pada mata kuliah ini bisa menjadi syarat keberhasilan pada mata kuliah yang lainnya.

Berdasarkan hasil analisis data, didapat bahwa kontribusi variabel mathematics anxiety hanya sebesar 35\%. Selebihnya dipengaruhi oleh faktor lain seperti kemampuan awal mahasiswa, self-concept siswa, motivasi baik itu 
dari dirinya sendiri, keluarga dan lingkungan. Disamping itu faktor kematangan usia dimana mahasiswa tingkat awal termasuk dalam rentang remaja. Individu dengan rentang usia remaja lebih bisa mengembangkan dalam pengontrolan kecemasan belajarnya sehingga mereka lebih mampu mengevaluasi berbagai macam tekanan, tantangan yang ada di sekitar mereka. Dengan kecemasan belajar yang mulai terkontrol tersebut, mahasiswa lebih mampu percaya diri dalam mengambil sikap serta perbuatan dalam belajar khususnya pembelajaran kalkulus. Sehingga pada waktu menghadapi UTS dan UAS mahasiswa akan jauh lebih siap.

\section{Simpulan dan Saran}

Berdasarkan hasil penelitian yang telah dilakukan pada mahasiswa tingkat awal Program Studi Pendidikan Matematika Universitas Muhammadiyah Cirebon, maka dapat diambil kesimpulan bahwa terdapat hubungan yang negatif dan signifikan antara mathematics anxiety dengan kemampuan akademik mahasiswa. Artinya, mathematics anxiety dapat digunakan untuk memprediksikan tingkat kemampuan akademik mahasiswa. Serta mathematics anxiety memiliki kontribusi sebesar 35\% terhadap kemampuan akademik mahasiswa, selebihnya sebesar 65\% dipengaruhi oleh variabel lain. Berdasarkan kesimpulan penelitian, diajukan beberapa saran sebagai berikut: Mathematics anxiety sekiranya dapat digunakan untuk memprediksikan tingkat kemampuan akademik mahasiswa, baik pada pembelajaran kalkulus maupun pada pembelajaran lainnya; perlu dilakukan penelitian lanjutan terkait pengembangan model pembelajaran dan pengembangan buku ajar pada pembelajaran kalkulus; aspek afektif yang diukur dalam penelitian ini hanya mathematics anxiety, sekiranya perlu dilakukan dari aspek afektif yang lain dalam memprediksi kemampuan akademik mahasiswa pada pembelajaran kalkulus.

\section{Daftar Pustaka}

Anita, I. W. 2011. Pengaruh Kecemasan (Mathematics Anxiety) Terhadap Kemampuan Pemecahan Masalah dan Koneksi Matematis Siswa SMP. Sekolah Pascasarjana UPI Bandung. Tesis. Tidak Diterbitkan.

Anggreini, T. 2010. Hubungan antara Kecemasan dalam Menghadapi Mata Pelajaran Matematika dengan Prestasi Akademik Matematika pada Remaja.

Dilihat 15 September 2017, http://www.gunadarma.ac.id/library Larticles/graduate/psychology/2010/Artikel_10505235.pdf

Ashcraft, M.H. 2002. "Math Anxiety: Personal, Educational, and Cognitive Consequences". Directions in Psychological Science. 11.

JNPM (Jurnal Nasional Pendidikan Matematika) Vol. 2, No. 2, Hal. 206-216 p-ISSN 2549-8495, e-ISSN 2549-4937 @Prodi Pendidikan Matematika Unswagati Cirebon 
Djiwandono dan Wuryani, S., E. 2009. Psikologi Pendidikan. Jakarta: PT Grasindo.

Ekawati, A. 2015. Pengaruh Kecemasan terhadap Hasil Belajar Matematika Siswa Kelas VII SMPN 13 Banjarmasin. Math Didactic: Jurnal Pendidikan Matematika, Vol 1, No. 3, September-Desember 2015, ISSN 2442-3041

Ghufron, N dan Risnawati, R. 2010. Teori-Teori Psikologi. Jogjakarta: Ar-Ruzz Media.

Mathison, M. 1977. Curricular interventions and programminginnovations for the reduction of mathematics anxiety. Retrieved on October 1, 2001 from ERIC database (\#ED154430).

Plaisance, D.V. 2009. "Mathematics Anxiety of Preservice Elementary Teachers After Completing a Problem Solving Course". Louisiana Association of Teachers (LATM) Journal, 5, (1).

Singgih, dan Yulia. 2012. Psikologi Perawatan. Jakarta: Libri.

Sugiyono. 2012. Statistika untuk Penelitian. Alfabeta: Bandung.

Sukmadinata, N., S. 2005. Landasan sikologi Proses Pendidikan. Bandung: Remaja Rosdakarya.

Syah, M. 2012. Psikologi Belajar. Jakarta: Rajagrafindo Persada.

Yuliana. (2013). Pengaruh Pendekatan Differentiated Instruction (DI) Terhadap Kemampuan Pemahaman, Penalaran,dan Kecemasan Matematika (Math Anxiety) Siswa SMK. Sekolah Pascasarjana UPI Bandung. Tesis. Tidak diterbitkan. 